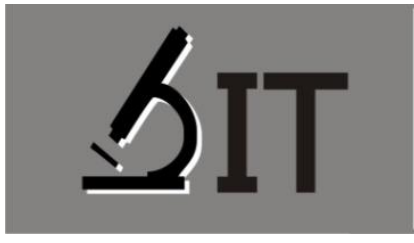

p-ISSN : 2597-8977

e-ISSN : 2597-8985

Dewi Kartika *)

Prodi Pendidikan IPA

Ratnawaty Maming

Universitas Negeri Makassar

Muh Tawil

Universitas Negeri Makassar

*) Correspondence Author: dewi.kartika166@yahoo.co.id
JIT 3 (2) (2020) 10-23

JURNAL IPA TERPADU

http://ojs.unm.ac.id/index.php/ipaterpadu

\section{IDENTIFIKASI MISKONSEPSI MATA PELAJARAN IPA PESERTA DIDIK KELAS VIII SMPN TERAKREDITASI A DI KABUPATEN GOWA}

Abstrak: Penelitian ini bertujuan untuk: (1) Mengetahui tingkat miskonsepsi mata pelajaran IPA peserta didik laki-laki kelas VIII SMPN Terakreditasi A di Kabupaten Gowa, (2) Mengetahui tingkat miskonsepsi mata pelajaran IPA peserta didik perempuan kelas VIII SMPN Terakreditasi A di Kabupaten Gowa, (3) Mengetahui tingkat miskonsepsi mata pelajaran IPA peserta didik kelas VIII SMPN Terakreditasi A di Kabupaten Gowa secara keseluruhan. Penelitian ini adalah penelitian survey dengan desain penelitian survey deskriptif. Populasi penelitian ini adalah seluruh peserta didik kelas VIII SMPN Terakreditasi A di Kabupaten Gowa. Pengambilan sampel dengan teknik Cluster Sampling sehingga diperoleh satu kelas dari masing-masing sekolah yang Terakreditasi A yang terdiri dari 229 peserta didik, 138 peserta didik perempuan dan 91 peserta didik laki-laki. Berdasarkan hasil penelitian menunjukkan bahwa : (1) Tingkat miskonsepsi mata pelajaran IPA peserta didik laki-laki kelas VIII SMPN Terakreditasi A di Kabupaten Gowa termasuk dalam kategori tinggi, (2) Tingkat miskonsepsi mata pelajaran IPA peserta didik perempuan kelas VIII SMPN Terakreditasi A di Kabupaten Gowa termasuk dalam kategori tinggi, (3) Tingkat miskonsepsi mata pelajaran IPA peserta didik kelas VIII SMPN Terakreditasi A di Kabupaten Gowa secara keseluruhan termasuk dalam kategori tinggi.

Kata Kunci: Miskonsepsi, Three Tier Test

Abstract: This study aims: (1) Determine the level of misconception in science subjects in grade VIII accredited A Public Junior High School in Gowa Regency, (2) Know the level of misconception in science subjects for Class VIII female students of Accredited A Middle School in Gowa, (3) Knowing the level of misconception in science subjects for Grade VIII students of Accredited A Middle School in Gowa Regency as a whole. This research is a survey research with descriptive survey research design. The population of this study was all students of class VIII Accredited A Middle School in Gowa Regency. Sampling with Cluster Sampling technique in order to obtain one class from each of the Accredited A schools consisting of 229 students, 138 female students and 91 male students. Based on the results of the study showed that: (1) The level of misconception of science subjects in Grade VIII male students of SMP A Accredited A in Gowa Regency is included in the high category, (2) The level of misconception of science subjects of Grade VIII female students of SMP A Accredited A in Regency Gowa is included in the high category, (3) The level of misconception in science subjects for Grade VIII students of SMP A Accredited A in Gowa Regency overall is included in the high category

Keyword: Misconception, Three Tier Test 


\section{PENDAHULUAN}

Pendidikan sains yang berkualitas dipengaruhi oleh lima ranah yaitu pemahaman konsep, keterampilan proses, kreativitas, pengembangan sikap dan penggunaan konsep dalam kehidupan sehari-hari.Salah Satu tujuan pembelajaran yang penting adalah membantu peserta didik memahami konsep.

Salah satu bidang ilmu yang banyak berisikan konsep adalah IPA. IImu pengetahuan alam merupakan ilmu yang diperoleh melalui investigasi yang bersifat eksperimen dan eksplanasi teoritis atas fenomena-fenomena yang terjadi dialam sekitar. Fenomena-fenomena alam tersebut dipahami oleh para ilmuwan dalam bentuk konsepsi yang bersifat ilmiah (Andarini, 2012).

Rendahnya penguasaan konsep peserta didik dapat disebabkan oleh kesulitan belajar dan terjadinya miskonsepsi Carey ( 1986). Miskonsepsi harus terlebih dahulu diidentifikasi sebelum diperbaiki. Identifikasi bertujuan membedakan siswa yang paham konsep, miskonsepsi dan tidak paham konsep. Identifikasi miskonsepsi diperlukan dalam mengembangkan strategi untuk membentuk pengetahuan yang benar pada peserta didik.

Pemilihan metode yang tepat dalam mengidentifikasi miskonsepsi sangat penting. Salah satu cara yang dapat dilakukan untuk mengetahui miskonsepsi peserta didik adalah dengan melakukan tes diagnostik. Arikunto (2016) Menyataan bahwa tes diagnostik adalah tes yang digunakan untuk mengetahui kelemahan-kelemahan peserta didik sehingga dapat dilakukan penanganan yang tepat.

Three-tier test merupakan instrumen dengan tiga tingkatan; content tier yang mengukur pengetahuan responden terkait suatu konsep/materi, reason tier untuk melihat alasan dibalik jawaban yang diberikan oleh responden pada content tier, dan certainty respon index yang mengukur seberapa percaya diri responden akan jawabannya di tingkat pertama dan kedua (Arslan, 2012). Jenis test ini dianggap mampu mendiagnosa konsepsi/ miskonsepsi siswa dengan baik, sebab terdapat tingkat kedua dari tes yang menanyakan alasan untuk jawaban responden di tingkat pertama dan juga tingkat ketiga yang menanyakan seberapa percaya diri responden dengan jawabannya.

Berdasarkan uraian di atas, maka tujuan penelitian ini sebagai berikut:

1) Untuk mengetahui tingkat miskonsepsi mata pelajaran IPA peserta didik laki-laki kelas VIII SMPN Terakreditasi A di Kabupaten Gowa.

2) Untuk mengetahui tingkat miskonsepsi mata pelajaran IPA peserta didik perempuan kelas VIII SMPN Terakreditasi A di Kabupaten Gowa.

3) Untuk mengetahui tingkat miskonsepsi mata pelajaran IPA peserta didik kelas VIII SMPN Terakreditasi A di Kabupaten Gowa secara keseluruhan.

Miskonsepsi adalah suatu pemahaman konsep yang salah yang terjadi pada siswa, karena bertentangan dengan konsep yang sebenarnya yang telah disepakati oleh para ahli. Kesalahan konsep tersebut karena siswa mengembangkan pemahaman mereka sendiri berdasarkan apa yang mereka lihat dan dengar, untuk memahami suatu konsep yang mereka pelajari tanpa mereka sadari bahwa konsep yang mereka yakini sebenarnya salah.

Adapun interpretasi respon yang diberikan oleh responden menurut Arslan (2012) digambarkan dalam tabel 1 berikut: 
Tabel 1. Kemungkinan Respon Three Tier Test

\begin{tabular}{cccc}
\hline Tingkat Pertama & Tingkat Kedua & Tingkat Ketiga & Kategori \\
\hline Benar & Benar & Yakin & Paham konsep \\
Benar & Salah & Yakin & Miskonsepsi \\
Salah & Benar & Yakin & Miskonsepsi \\
Salah & Salah & Yakin & Miskonsepsi \\
Benar & Benar & Tidak Yakin & Tebakan beruntung, kurang kepercayaan diri \\
Benar & Salah & Tidak Yakin & Kurangnya pemahaman konsep \\
Salah & Benar & Tidak Yakin & Kurangnya pemahaman konsep \\
Salah & Salah & Tidak Yakin & Kurangnya pemahaman konsep \\
\hline
\end{tabular}

Hasil penelitian yang relevan dan menjadi rujukan dalam pelaksanaan penelitian ini salah satunya yaitu penelitian yang dilakukan oleh Siswana, Armen, \& Helendra (2017) bahwa siswa kelas IX SMPN 7 Padang mengalami miskonsepsi pada semua submateri tentang fotosintesis yang diujikan dengan tes pemahaman konsep dengan persentase yang berbeda-beda. Selain itu, penelitian terkait lainnya oleh Mustaqim (2014) bahwa persentase siswa yang mengalami miskonsepsi pada konsep Fotosintesis dan Respirasi Tumbuhan sebesar 37,69\% dan lebih kecil daripada persentase siswa yang tidak tahu konsep.

\section{METODE}

Jenis penelitian yang digunakan adalah metode penelitian survey dengan desain penelitian yang digunakan adalah survey deskriptif. Penelitian dilaksanakan pada Semester semester ganjil tahun ajaran 2019/2020. Pengambilan sampel dilakukan dengan teknik Cluster Sampling dimana kecamatan yang ada di kabupaten Gowa diwakili satu sekolah yang Terakreditasi A dan setiap sekolah diwakili satu kelas yang dipilih secara acak oleh peneliti. Populasi dalam penelitian ini adalah seluruh peserta didik kelas VIII SMPN Terakreditasi A di kabupaten Gowa. Adapun sampel penelitiannya adalah sebagai berikut

\section{Tabel 2. Sampel Penelitian}

\begin{tabular}{ll}
\hline \multicolumn{1}{c}{ Nama Sekolah } & \multicolumn{1}{c}{ Alamat } \\
\hline SMPN 1 Tombolopao & Jl. A. Baso M No.12 Tombolo, TAMAONA, Kec. Tombolo Pao Kab. Gowa \\
SMPN 1 Tinggimoncong & Jl. A. Mappatangka No. 37 Malino, MALINO, Kec. Tinggi Moncong, Kab. Gowa \\
SMPN 1 Parangloe & Jl. Malino Km. 40, LANNA, Kec. Parang Loe, Kab. Gowa \\
SMPN 2 Pattallassang & Jl. Pallantikang, Pattallassang, Kec. Pattallassang, Kab. Gowa \\
SMPN 1 Sungguminasa & Jl. H. Habibu Kulle No. 25, Sungguminasa, Kec. Somba Opu, Kab. Gowa \\
SMPN 1 Pallangga & Jl. Pembangunan No. 3 Pallangga, Mangalili, Kec. Pallangga, Kab. Gowa \\
SMPN 1 Bajeng & Jl. Batang Banoa No. 3 Bajeng, Limbung, Kec. Bajeng, Kab. Gowa \\
SMPN 1 Bontonompo & Jl. Pendidikan No. 16, Tamallayang, Kec. Bontonompo, Kab. Gowa \\
\hline
\end{tabular}

Sumber : Badan Akreditasi Nasional Sekolah/Madrasah http://bansm.kemdikbud.go.id/akreditasi

Data diperoleh dari hasil tes pilihan ganda yang dilengkapi dengan pilihan alasan dengan metode certainly of response index (CRI) yang disebut dengan Three tier test yang berjumlah 20 butir soal.

Adapun tahapan teknik analisis data yang digunakan adalah sebagai berikut :

1) Mengidentifikasi hasil tes peserta didik dengan melihat hasil jawaban peserta didik. 
2) Menentukan kategori pemahaman peserta didik yang paham konsep, miskonsepsi, tebakan beruntung/kurang kepercayaan diri dan kurangnya pemahaman konsep dengan berpatokan pada tabel 2

3) Menghitung persentase miskonsepsi jawaban peserta didik dengan rumus sebagai berikut (Sudijono, 2015):

$p=\frac{f}{N} \times 100 \%$

Keterangan:

$p$ : Persentase miskonsepsi peserta didik

$f$ : Jumlah peserta didik miskonsepsi

$N$ : Jumlah individu (jumlah seluruh peserta didik yang menjadi sampel)

4) Membuat rekapitulasi persentase rata-rata miskonsepsi peserta didik.

5) Setelah persentase miskonsepsi telah didapatkan, selanjutnya mengkategorikan miskonsepsi tersebut menjadi kategori tinggi, sedang atau rendah berdasarkan persentasenya. Berikut ini adalah indikator pengkategorian miskonsepsi yang ditunjukkan pada tabel 3

Tabel 3. Indikator Pengkategorian Tingkat Miskonsepsi

\begin{tabular}{ccc}
\hline NO. & Persentase & Kategori \\
\hline 1 & $0-30 \%$ & Rendah \\
2 & $31 \%-60 \%$ & Sedang \\
3 & $61 \%-100 \%$ & Tinggi \\
\hline
\end{tabular}

Sumber : (Suwarna, 2013)

6) Hasil pengolahan data ini selanjutnya akan mengarah pada kesimpulan.

\section{HASIL DAN PEMBAHASAN}

1. Hasil

a. Persentase Miskonsepsi Peserta Didik Laki-Laki

1) Persentase Miskonsepsi Peserta Didik Laki-laki Pada Semua Soal

Tabel 4. Persentase Miskonsepsi

\begin{tabular}{lccc}
\hline Tingkat Pemahaman & Jumlah & Persentase & Kategori \\
\hline Miskonsepsi & 1224 & $67 \%$ & Tinggi \\
\hline
\end{tabular}

Hasil rekapitulasi persentase miskonsepsi peserta didik laki-laki pada semua soal disajikan dalam bentuk diagram batang. Hasil ini bertujuan untuk melihat gambaran keseluruhan mengenai persentase miskonsepsi peserta didik laki-laki dari semua soal. Berikut ini adalah rekapitulasi persentase miskonsepsi peserta didik laki-laki pada semua soal yang ditunjukkan gambar 1. 


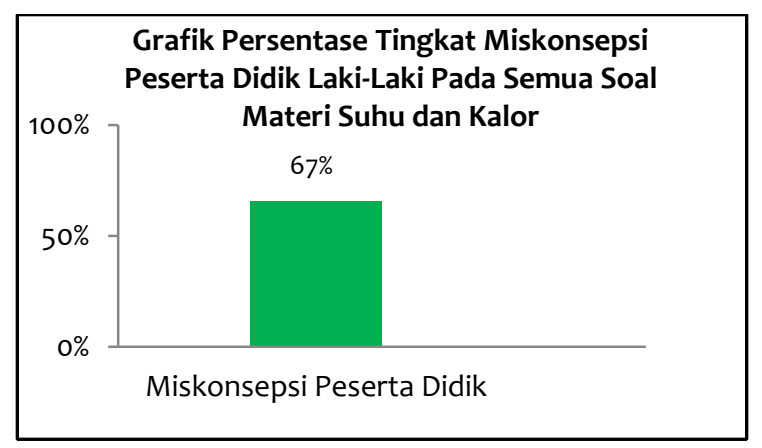

\section{Gambar 1. Grafik Persentase Miskonsepsi Pada Semua Butir Soal}

Dari gambar dapat diketahui bahwa pada semua soal yang telah dikerjakan, secara keseluruhan pada semua butir soal peserta didik laki-laki yang teridentifikasi mengalami miskonsepsi memiliki persentase yaitu sebesar $67 \%$.

\section{2) Persentase Miskonsepsi Peserta Didik Laki-laki Pada Setiap Butir Soal}

\section{Tabel 5. Persentase Miskonsepsi}

\begin{tabular}{|c|c|c|c|c|}
\hline $\begin{array}{l}\text { Butir } \\
\text { Soal }\end{array}$ & Indikator Soal & $\begin{array}{c}\text { Jumlah } \\
\text { Peserta } \\
\text { Didik }\end{array}$ & Persentase & Kategori \\
\hline 1 & Menjelaskan konsep suhu & 69 & $76 \%$ & Tinggi \\
\hline 2 & Membandingkan suhu suatu benda tertentu & 65 & $71 \%$ & Tinggi \\
\hline 3 & $\begin{array}{l}\text { Mengidentifikasi pengaruh kalor jenis terhadap perubahan } \\
\text { suhu benda }\end{array}$ & 66 & $73 \%$ & Tinggi \\
\hline 4 & Mengidentifikasi pemuaian zat padat & 53 & $58 \%$ & Sedang \\
\hline 5 & $\begin{array}{l}\text { Mengidentifikasi pemuaian zat padat pada kehidupan } \\
\text { sehari-hari }\end{array}$ & 60 & $66 \%$ & Tinggi \\
\hline 6 & $\begin{array}{l}\text { Mengidentifikasi faktor-faktor yang mempengaruhi } \\
\text { perpindahan kalor }\end{array}$ & 72 & $79 \%$ & Tinggi \\
\hline 7 & Mengidentifikasi akibat perubahan kalor & 55 & $60 \%$ & Sedang \\
\hline 8 & Membandingkan suatu benda yang menerima kalor & 62 & $68 \%$ & Tinggi \\
\hline 9 & Mengidentifikasi proses perpindahan kalor & 63 & $69 \%$ & Tinggi \\
\hline 10 & Mengidentifikasi proses perpindahan kalor & 74 & $81 \%$ & Tinggi \\
\hline 11 & Membandingkan kalor jenis suatu benda & 62 & $68 \%$ & Tinggi \\
\hline 12 & Mengidentifikasi perubahan wujud zat & 68 & $75 \%$ & Tinggi \\
\hline 13 & Menguraikan proses perubahan wujud zat & 56 & $62 \%$ & Tinggi \\
\hline 14 & Memberi contoh perubahan wujud yang melepas kalor & 59 & $65 \%$ & Tinggi \\
\hline 15 & $\begin{array}{l}\text { Mengidentifikasi kalor akibat perubahan suhu ketika benda } \\
\text { bersentuhan }\end{array}$ & 54 & $59 \%$ & Sedang \\
\hline 16 & $\begin{array}{l}\text { Menganalisis pengaruh kalor terhadap perubahan wujud } \\
\text { benda }\end{array}$ & 53 & $58 \%$ & Sedang \\
\hline 17 & $\begin{array}{l}\text { Membedakan perpindahan kalor secara konduksi, konveksi } \\
\text { dan radiasi }\end{array}$ & 52 & $57 \%$ & Sedang \\
\hline 18 & $\begin{array}{l}\text { Mengidentifikasi perpindahan kalor secara konduksi pada } \\
\text { kehidupan sehari-hari }\end{array}$ & 65 & $71 \%$ & Tinggi \\
\hline 19 & $\begin{array}{l}\text { Mengidentifikasi perpindahan kalor secara konveksi pada } \\
\text { kehidupan sehari-hari }\end{array}$ & 53 & $58 \%$ & Sedang \\
\hline 20 & $\begin{array}{l}\text { Mengidentifikasi perpindahan kalor secara radiasi pada } \\
\text { kehidupan sehari-hari }\end{array}$ & 63 & $69 \%$ & Tinggi \\
\hline
\end{tabular}


Hasil rekapitulasi persentase tingkat miskonsepsi peserta didik pada tiap butir soal disajikan dalam bentuk diagram batang. Hasil ini bertujuan untuk melihat gambaran keseluruhan mengenai persentase tingkat miskonsepsi peserta didik pada setiap butir soal materi suhu dan kalor. Berikut ini adalah rekapitulasi persentase peserta didik pada setiap butir soal yang ditunjukkan gambar 2

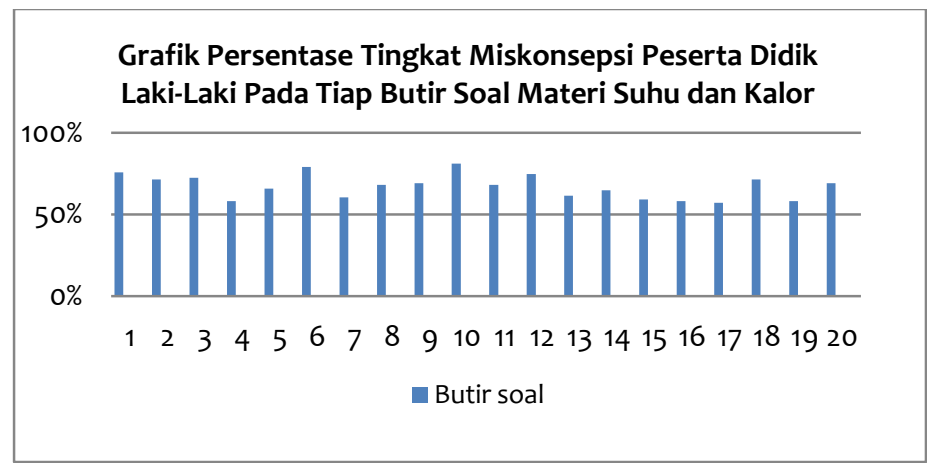

Gambar 2. Grafik Persentase Miskonsepsi Pada Setiap Butir Soal

Berdasarkan gambar dapat diketahui bahwa peserta didik laki-laki yang teridentifikasi mengalami miskonsepsi memiliki persentase yang paling tinggi pada butir soal nomor 10 dan 6 yaitu ( $81 \%$ dan $79 \%)$, dibandingkan butir soal nomor $1(76 \%)$, soal nomor $2(71 \%)$, soal nomor $3(73 \%)$, soal nomor $4(58 \%)$, soal nomor $5(66 \%)$, soal nomor $7(60 \%)$, soal nomor $8(68 \%)$, soal nomor 9 (69\%), soal nomor $11(68 \%)$, soal nomor $12(75 \%)$, soal nomor $13(62 \%)$, soal nomor $14(65 \%)$, soal nomor 15 (59\%), soal nomor 16 (58\%), soal nomor 17 (57\%), soal nomor 18 (71\%), soal nomor 19 (58\%), serta soal nomor $20(69 \%)$.

\section{b. Persentase Miskonsepsi Peserta Didik Perempuan}

\section{a. Persentase Miskonsepsi Peserta Didik Perempuan Pada Semua Soal}

Tabel 6. Persentase Miskonsepsi

\begin{tabular}{cccc}
\hline Tingkat Pemahaman & Jumlah & Persentase & Kategori \\
\hline Miskonsepsi & 1768 & $64 \%$ & Rendah \\
\hline
\end{tabular}

Hasil rekapitulasi persentase miskonsepsi peserta didik perempuan pada semua soal disajikan dalam bentuk diagram batang.Berikut ini adalah rekapitulasi persentase miskonsepsi peserta didik perempuan pada semua soal yang ditunjukkan gambar 3 .

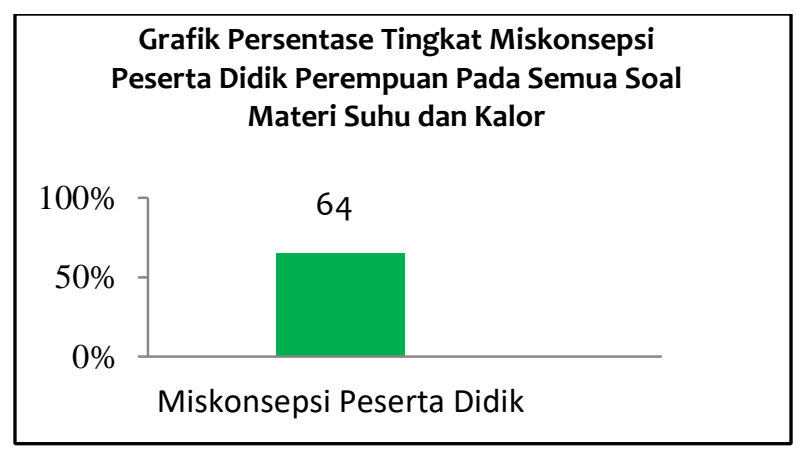

Gambar 3 Grafik Persentase Miskonsepsi Pada Semua Butir Soal 
Dari gambar dapat diketahui bahwa pada semua soal yang telah dikerjakan, secara keseluruhan pada semua butir soal peserta didik perempuan yang teridentifikasi mengalami miskonsepsi memiliki persentase yaitu sebesar $64 \%$.

\section{b. Persentase Miskonsepsi Peserta Didik Perempuan Pada Setiap Butir Soal}

Tabel 7. Persentase Miskonsepsi

\begin{tabular}{|c|c|c|c|c|}
\hline $\begin{array}{l}\text { Butir } \\
\text { Soal }\end{array}$ & Indikator Soal & $\begin{array}{c}\text { Jumlah } \\
\text { Peserta } \\
\text { Didik } \\
\end{array}$ & Persentase & Kategori \\
\hline 1 & Menjelaskan konsep suhu & 111 & $80 \%$ & Tinggi \\
\hline 2 & Membandingkan suhu suatu benda tertentu & 92 & $67 \%$ & Tinggi \\
\hline 3 & $\begin{array}{l}\text { Mengidentifikasi pengaruh kalor jenis terhadap } \\
\text { perubahan suhu benda }\end{array}$ & 94 & $68 \%$ & Tinggi \\
\hline 4 & Mengidentifikasi pemuaian zat padat & 78 & $57 \%$ & Sedang \\
\hline 5 & $\begin{array}{l}\text { Mengidentifikasi pemuaian zat padat pada kehidupan } \\
\text { sehari-hari }\end{array}$ & 88 & $64 \%$ & Tinggi \\
\hline 6 & $\begin{array}{l}\text { Mengidentifikasi faktor-faktor yang mempengaruhi } \\
\text { perpindahan kalor }\end{array}$ & 96 & $70 \%$ & Tinggi \\
\hline 7 & Mengidentifikasi akibat perubahan kalor & 80 & $58 \%$ & Sedang \\
\hline 8 & Membandingkan suatu benda yang menerima kalor & 78 & $57 \%$ & Sedang \\
\hline 9 & Mengidentifikasi proses perpindahan kalor & 103 & $75 \%$ & Tinggi \\
\hline 10 & Mengidentifikasi proses perpindahan kalor & 99 & $72 \%$ & Tinggi \\
\hline 11 & Membandingkan kalor jenis suatu benda & 88 & $64 \%$ & Tinggi \\
\hline 12 & Mengidentifikasi perubahan wujud zat & 98 & $71 \%$ & Tinggi \\
\hline 13 & Menguraikan proses perubahan wujud zat & 85 & $62 \%$ & Tinggi \\
\hline 14 & Memberi contoh perubahan wujud yang melepas kalor & 71 & $51 \%$ & Sedang \\
\hline 15 & $\begin{array}{l}\text { Mengidentifikasi kalor akibat perubahan suhu ketika } \\
\text { benda bersentuhan }\end{array}$ & 69 & $50 \%$ & Sedang \\
\hline 16 & $\begin{array}{l}\text { Menganalisis pengaruh kalor terhadap perubahan wujud } \\
\text { benda }\end{array}$ & 85 & $62 \%$ & Tinggi \\
\hline 17 & $\begin{array}{l}\text { Membedakan perpindahan kalor secara konduksi, } \\
\text { konveksi dan radiasi }\end{array}$ & 83 & $60 \%$ & Sedang \\
\hline 18 & $\begin{array}{l}\text { Mengidentifikasi perpindahan kalor secara konduksi pada } \\
\text { kehidupan sehari-hari }\end{array}$ & 88 & $64 \%$ & Tinggi \\
\hline 19 & $\begin{array}{l}\text { Mengidentifikasi perpindahan kalor secara konveksi pada } \\
\text { kehidupan sehari-hari }\end{array}$ & 83 & $60 \%$ & Sedang \\
\hline 20 & $\begin{array}{l}\text { Mengidentifikasi perpindahan kalor secara radiasi pada } \\
\text { kehidupan sehari-hari }\end{array}$ & 99 & $72 \%$ & Tinggi \\
\hline
\end{tabular}

Hasil rekapitulasi persentase rata-rata tingkat miskonsepsi peserta didik disajikan dalam bentuk diagram batang. Hasil ini bertujuan untuk melihat gambaran keseluruhan mengenai persentase tingkat miskonsepsi peserta didik pada setiap butir soal materi suhu dan kalor. Berikut ini adalah rekapitulasi persentase peserta didik pada setiap butir soal yang ditunjukkan gambar 4 


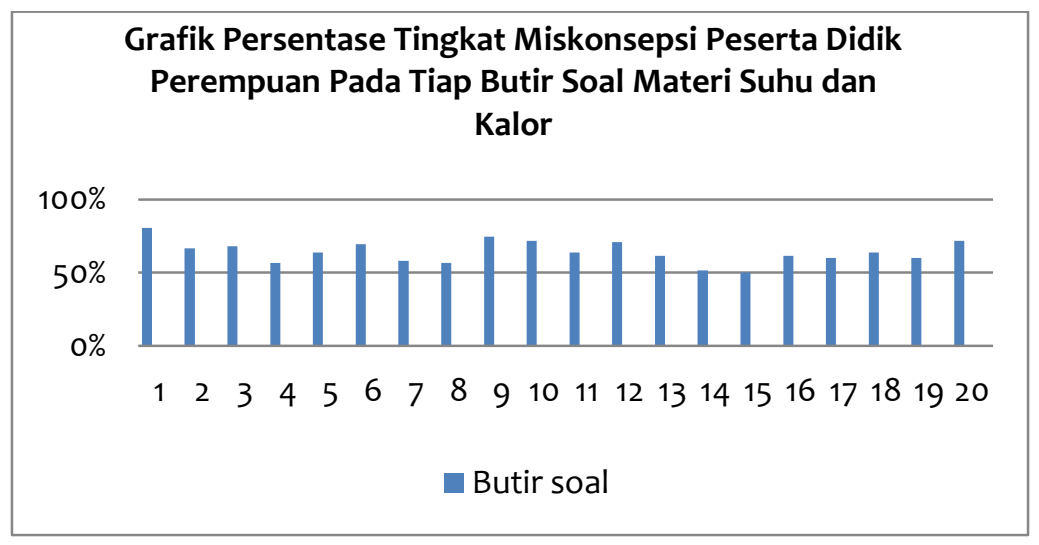

Gambar 4. Grafik Persentase Miskonsepsi Pada Setiap Butir Soal

Berdasarkan gambar dapat diketahui bahwa peserta didik perempuan yang teridentifikasi mengalami miskonsepsi memiliki persentase yang paling tinggi pada butir soal nomor 1 dan 9 yaitu ( $80 \%$ dan $75 \%$ ), dibandingkan soal nomor $2(67 \%)$, soal nomor $3(68 \%)$, soal nomor $4(57 \%)$, soal nomor $5(64 \%)$, soal nomor $6(70 \%)$, soal nomor $7(58 \%)$, soal nomor $8(57 \%)$, soal nomor 10 (72\%), soal nomor $11(64 \%)$, soal nomor $12(71 \%)$, soal nomor $13(62 \%)$, soal nomor $14(51 \%)$, soal nomor 15 (50\%), soal nomor 16 (62\%), soal nomor 17 (60\%), soal nomor $18(64 \%)$, soal nomor 19 (60\%), serta soal nomor $20(72 \%)$.

\section{c. Persentase Miskonsepsi Peserta Didik Keseluruhan}

\section{a. Persentase Miskonsepsi Peserta Didik Secara Keseluruhan Pada Semua Butir Soal}

Tabel 8. Persentase Miskonsepsi

\begin{tabular}{cccc}
\hline Tingkat Pemahaman & Jumlah & Persentase & Kategori \\
\hline Miskonsepsi & 2992 & $65 \%$ & Tinggi \\
\hline
\end{tabular}

Hasil rekapitulasi persentase miskonsepsi seluruh peserta didik pada semua soal disajikan dalam bentuk diagram batang. Hasil ini bertujuan untuk melihat gambaran keseluruhan mengenai persentase miskonsepsi peserta didik secara keseluruhan dari semua soal. Berikut ini adalah rekapitulasi persentase miskonsepsi seluruh peserta didik pada semua soal yang ditunjukkan gambar 5

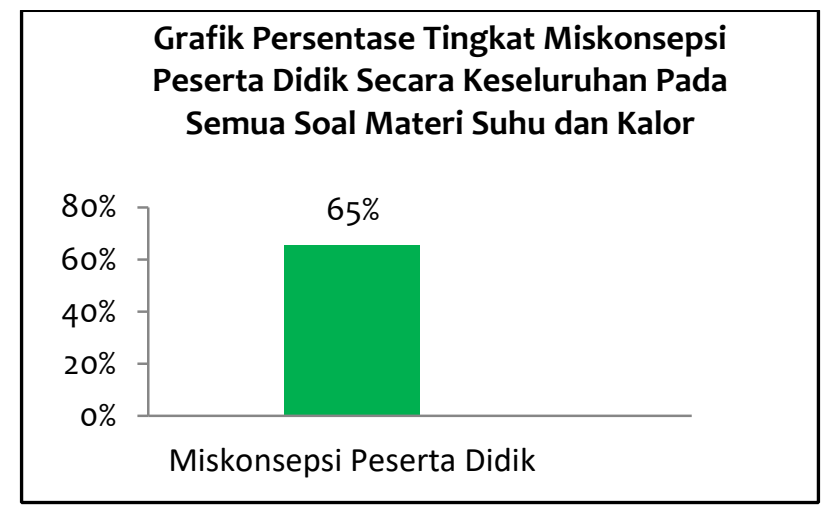

Gambar 5. Grafik Persentase Miskonsepsi Pada Semua Butir Soal 
Dari gambar dapat diketahui bahwa pada semua soal yang telah dikerjakan, secara keseluruhan pada semua butir soal seluruh peserta didik yang teridentifikasi mengalami miskonsepsi memiliki persentase yaitu sebesar $65 \%$.

\section{b. Persentase Miskonsepsi Peserta Didik Secara Keseluruhan Pada Setiap Butir Soal}

Tabel 9. Persentase Miskonsepsi

\begin{tabular}{|c|c|c|c|c|}
\hline $\begin{array}{l}\text { Butir } \\
\text { Soal }\end{array}$ & Indikator Soal & $\begin{array}{c}\text { Jumlah } \\
\text { Peserta } \\
\text { Didik }\end{array}$ & Persentase & Kategori \\
\hline 1 & Menjelaskan konsep suhu & 180 & $79 \%$ & Tinggi \\
\hline 2 & Membandingkan suhu suatu benda tertentu & 157 & $69 \%$ & Tinggi \\
\hline 3 & $\begin{array}{l}\text { Mengidentifikasi pengaruh kalor jenis terhadap perubahan } \\
\text { suhu benda }\end{array}$ & 160 & $70 \%$ & Tinggi \\
\hline 4 & Mengidentifikasi pemuaian zat padat & 131 & $57 \%$ & Sedang \\
\hline 5 & $\begin{array}{l}\text { Mengidentifikasi pemuaian zat padat pada kehidupan sehari- } \\
\text { hari }\end{array}$ & 148 & $65 \%$ & Tinggi \\
\hline 6 & $\begin{array}{l}\text { Mengidentifikasi faktor-faktor yang mempengaruhi } \\
\text { perpindahan kalor }\end{array}$ & 168 & $73 \%$ & Tinggi \\
\hline 7 & Mengidentifikasi akibat perubahan kalor & 135 & $59 \%$ & Sedang \\
\hline 8 & Membandingkan suatu benda yang menerima kalor & 140 & $61 \%$ & Tinggi \\
\hline 9 & Mengidentifikasi proses perpindahan kalor & 166 & $72 \%$ & Tinggi \\
\hline 10 & Mengidentifikasi proses perpindahan kalor & 173 & $76 \%$ & Tinggi \\
\hline 11 & Membandingkan kalor jenis suatu benda & 150 & $66 \%$ & Tinggi \\
\hline 12 & Mengidentifikasi perubahan wujud zat & 166 & $72 \%$ & Tinggi \\
\hline 13 & Menguraikan proses perubahan wujud zat & 141 & $62 \%$ & Tinggi \\
\hline 14 & Memberi contoh perubahan wujud yang melepas kalor & 130 & $57 \%$ & Sedang \\
\hline 15 & $\begin{array}{l}\text { Mengidentifikasi kalor akibat perubahan suhu ketika benda } \\
\text { bersentuhan }\end{array}$ & 123 & $54 \%$ & Sedang \\
\hline 16 & $\begin{array}{l}\text { Menganalisis pengaruh kalor terhadap perubahan wujud } \\
\text { benda }\end{array}$ & 138 & $60 \%$ & Sedang \\
\hline 17 & $\begin{array}{l}\text { Membedakan perpindahan kalor secara konduksi, konveksi } \\
\text { dan radiasi }\end{array}$ & 135 & $59 \%$ & Sedang \\
\hline 18 & $\begin{array}{l}\text { Mengidentifikasi perpindahan kalor secara konduksi pada } \\
\text { kehidupan sehari-hari }\end{array}$ & 153 & $67 \%$ & Tinggi \\
\hline 19 & $\begin{array}{l}\text { Mengidentifikasi perpindahan kalor secara konveksi pada } \\
\text { kehidupan sehari-hari }\end{array}$ & 136 & $59 \%$ & Sedang \\
\hline 20 & $\begin{array}{l}\text { Mengidentifikasi perpindahan kalor secara radiasi pada } \\
\text { kehidupan sehari-hari }\end{array}$ & 162 & $71 \%$ & Tinggi \\
\hline
\end{tabular}

Hasil rekapitulasi persentase tingkat miskonsepsi peserta didik disajikan dalam bentuk diagram batang. Hasil ini bertujuan untuk melihat gambaran keseluruhan mengenai persentase tingkat miskonsepsi seluruh peserta didik pada setiap butir soal materi suhu dan kalor. Berikut ini adalah rekapitulasi persentase peserta didik pada setiap butir soal yang ditunjukkan gambar 6 


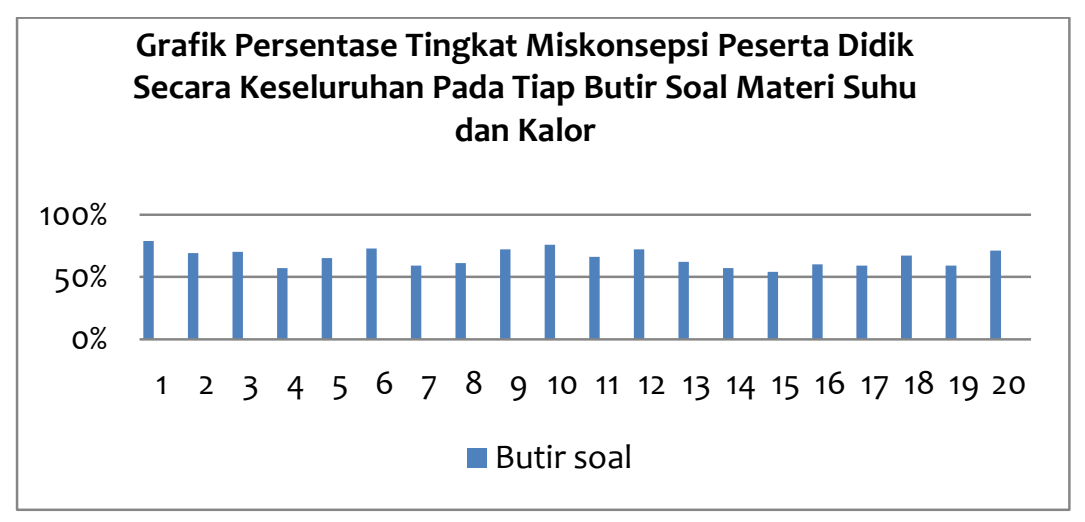

\section{Gambar 6. Grafik Persentase Miskonsepsi Pada Setiap Butir Soal}

Berdasarkan gambar dapat diketahui bahwa peserta didik yang teridentifikasi mengalami miskonsepsi memiliki persentase yang paling tinggi pada butir soal nomor 1 dan 10 yaitu ( $79 \%$ dan $76 \%)$, dibandingkan butir soal nomor $2(69 \%)$, soal nomor $3(70 \%)$, soal nomor $4(57 \%)$, soal nomor 5 (65\%), soal nomor $6(73 \%)$, soal nomor 7 (59\%), soal nomor $8(61 \%)$, soal nomor $972 \%$, soal nomor 11 (66\%), soal nomor $12(72 \%)$, soal nomor $13(62 \%)$, soal nomor $14(57 \%)$, soal nomor $15(54 \%)$, soal nomor $16(60 \%)$, soal nomor $17(59 \%)$, soal nomor $18(67 \%)$, soal nomor $19(59 \%)$, serta soal nomor $20(71 \%)$.

\section{Pembahasan}

\section{1) Persentase Miskonsepsi Peserta Didik Laki-Laki}

Perolehan data persentase miskonsepsi peserta didik laki-laki pada semua soal berdasarkan (gambar 1), diketahui bahwa dari seluruh peserta didik laki-laki yang berjumlah 91 peserta didik, persentase miskonsepsi termasuk dalam kategori tinggi.

Perolehan data persentase miskonsepsi peserta didik laki-laki disetiap butir soal dapat dilihat pada (gambar 2), teridentifikasi peserta didik mengalami miskonsepsi tertinggi pada indikator butir soal nomor 10 yaitu mengidentifikasi proses perpindahan kalor dengan persentase miskonsepsi termasuk dalam kategori tinggi. Miskonsepsi terendah terjadi pada butir soal nomor 17 yaitu membedakan perpindahan kalor secara konduksi,konveksi dan radiasi dengan persentase miskonsepsi termasuk dalam kategori sedang.

Adapun butir soal yang memiliki persentase tertinggi dapat dilihat pada gambar 7

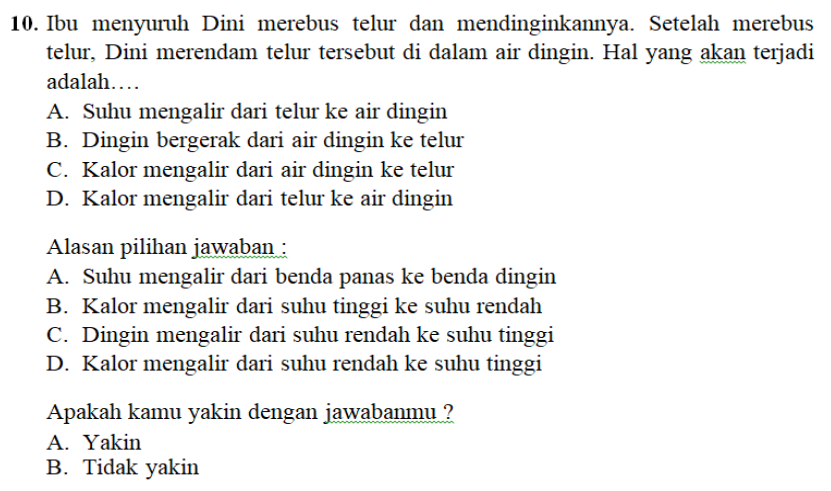


Indikator soal nomor 10 yaitu Mengidentifikasi proses perpindahan kalor. Pada soal ini teridentifikasi miskonsepsi yaitu suhu mengalir dari benda panas ke benda dingin. Ini merupakan miskonsepsi yang paling banyak dialami peserta didik laki-laki yaitu $81 \%$ dari total sampel. Peserta didik menganggap telur rebus menjadi dingin karena suhu mengalir ke air, padahal sebenarnya bukan suhu tetapi Kalor yang mengalir dari benda bersuhu tinggi ke benda bersuhu lebih rendah, sehingga menyebabkan telur menjadi dingin.

Miskonsepsi terjadi karena peserta didik menjawab dengan salah pada soal yang diberikan tetapi memiliki tingkat kepercayaan yang tinggi, sejalan dengan hasil penelitian (Arslan, 2012) bahwa miskonsepsi terjadi karena peserta didik menjawab dengan salah pada soal yang diberikan tetapi memiliki tingkat kepercayaan yang tinggi terhadap jawaban mereka.

\section{2) Persentase Miskonsepsi Peserta Didik Perempuan}

Perolehan data persentase miskonsepsi peserta didik perempuan pada semua soal berdasarkan (gambar 3), diketahui bahwa dari seluruh peserta didik perempuan yang berjumlah 138 peserta didik, persentase miskonsepsi teridentifikasi termasuk dalam kategori tinggi.

Perolehan data persentase miskonsepsi peserta didik perempuan disetiap butir soal dapat dilihat pada (gambar 4), teridentifikasi peserta didik mengalami miskonsepsi tertinggi pada indikator butir soal nomor 1 yaitu menjelaskan konsep suhu dengan persentase termasuk dalam kategori tinggi. Miskonsepsi terendah terjadi pada butir soal nomor 15 yaitu mengidentifikasi kalor akibat perubahan suhu ketika benda bersentuhan dengan persentase miskonsepsi termasuk dalam kategori sedang.

Adapun butir soal yang memiliki persentase tertinggi dapat dilihat pada gambar 8 . Indikator soal nomor 10 yaitu Menjelaskan konsep suhu. Pada soal ini teridentifikasi miskonsepsi yaitu suhu air panas ditentukan oleh jumlah air panas. Ini merupakan miskonsepsi yang paling banyak dialami peserta didik perempuan yaitu $80 \%$ dari total sampel. Peserta didik menganggap semakin banyak jumlah air panas maka suhu air semakin tinggi, padahal sebenarnya Suhu air dalam gelas kecil sama dengan suhu air dalam teko besar, Karena suhu suatu benda tidak bergantung banyak atau sedikitnya suatu benda.

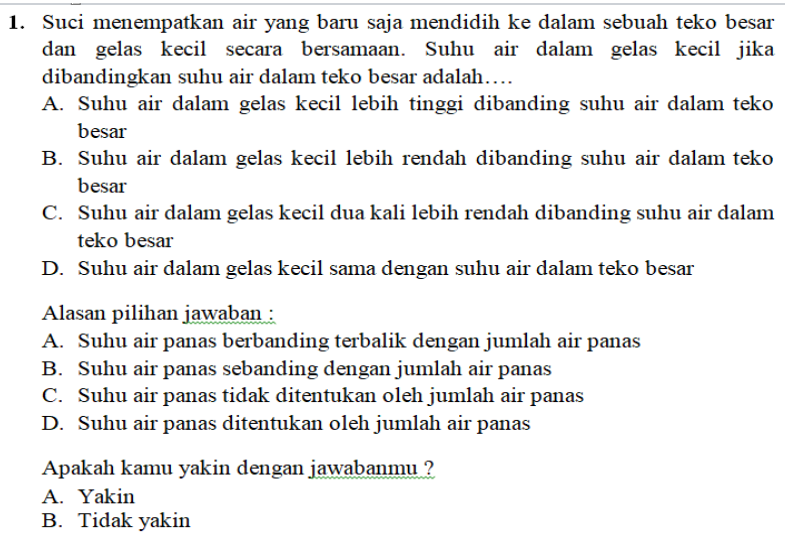

\section{Gambar 8. Soal Nomor 1}

Miskonsepsi terjadi karena peserta didik menjawab dengan salah pada soal yang diberikan tetapi memiliki tingkat kepercayaan yang tinggi, sejalan dengan hasil penelitian (Arslan, 2012) bahwa miskonsepsi terjadi karena peserta didik menjawab dengan salah pada soal yang diberikan tetapi memiliki tingkat kepercayaan yang tinggi terhadap jawaban mereka. 


\section{3) Persentase Miskonsepsi Seluruh Peserta Didik}

Perolehan data persentase miskonsepsi seluruh peserta didik berdasarkan gambar 5, diketahui bahwa peserta didik yang telah mendapatkan pengalaman belajar materi suhu dan kalor dan diuji dengan soal Three tier Test menunjukkan bahwa peserta didik masih banyak mengalami miskonsepsi ditunjukkan dengan tingginya persentase miskonsepsi peserta didik.

Berdasarkan hasil rekapitulasi persentase miskonsepsi seluruh peserta didik pada semua soal, persentase miskonsepsi peserta didik secara keseluruhan teridentifikasi termasuk dalam kategori tinggi.

Berdasarkan hasil rekapitulasi persentase miskonsepsi pada setiap butir soal menunjukkan bahwa peserta didik mengalami miskonsepsi pada setiap butir soal dengan kategori yang berbeda. Perolehan data persentase miskonsepsi seluruh peserta didik disetiap butir soal dapat dilihat pada gambar 6, teridentifikasi peserta didik mengalami miskonsepsi tertinggi pada indikator butir soal nomor 1 yaitu menjelaskan konsep suhu dengan persentase miskonsepsi termasuk dalam kategori tinggi. Miskonsepsi terendah terjadi pada butir soal nomor 15 yaitu mengidentifikasi kalor akibat perubahan suhu ketika benda bersentuhan dengan persentase miskonsepsi termasuk dalam kategori rendah.

Terdapat 14 butir soal yang memiliki persentase miskonsepsi dengan kategori tinggi. Soal nomor 1 yaitu menjelaskan konsep suhu, soal nomor 2 yaitu Membandingkan suhu suatu benda tertentu, soal nomor 3 yaitu Mengidentifikasi pengaruh kalor jenis terhadap perubahan suhu benda, soal nomor 5 yaitu Mengidentifikasi pemuaian zat padat pada kehidupan sehari-hari, soal nomor 6 yaitu Mengidentifikasi faktor-faktor yang mempengaruhi perpindahan kalor, soal nomor 8 yaitu Membandingkan suatu benda yang menerima kalor, soal nomor 9 yaitu Mengidentifikasi proses perpindahan kalor, soal nomor 10 yaitu Mengidentifikasi proses perpindahan kalor, soal nomor 11 yaitu Membandingkan kalor jenis suatu benda, soal nomor 12 yaitu Mengidentifikasi perubahan wujud zat, Soal nomor 13 yaitu Menguraikan proses perubahan wujud zat, Soal nomor 16 yaitu Menganalisis pengaruh kalor terhadap perubahan wujud benda, Soal nomor 18 yaitu Mengidentifikasi perpindahan kalor secara konduksi pada kehidupan sehari-hari, Soal nomor 20 yaitu Mengidentifikasi perpindahan kalor secara radiasi pada kehidupan sehari-hari.

Terdapat 6 butir soal yang memiliki persentase miskonsepsi dengan kategori sedang. Soal nomor 2 yaitu Mengidentifikasi pemuaian zat padat, Soal nomor 7 yaitu Mengidentifikasi akibat perubahan kalor, Soal nomor 14 yaitu Memberi contoh perubahan wujud yang melepas kalor, Soal nomor 15 yaitu Mengidentifikasi kalor akibat perubahan suhu ketika benda bersentuhan, Soal nomor 17 yaitu Membedakan perpindahan kalor secara konduksi, konveksi dan radiasi, Soal nomor 19 yaitu Mengidentifikasi perpindahan kalor secara konveksi pada kehidupan sehari-hari.

Adapun butir soal yang memiliki persentase tertinggi dapat dilihat pada gambar 9

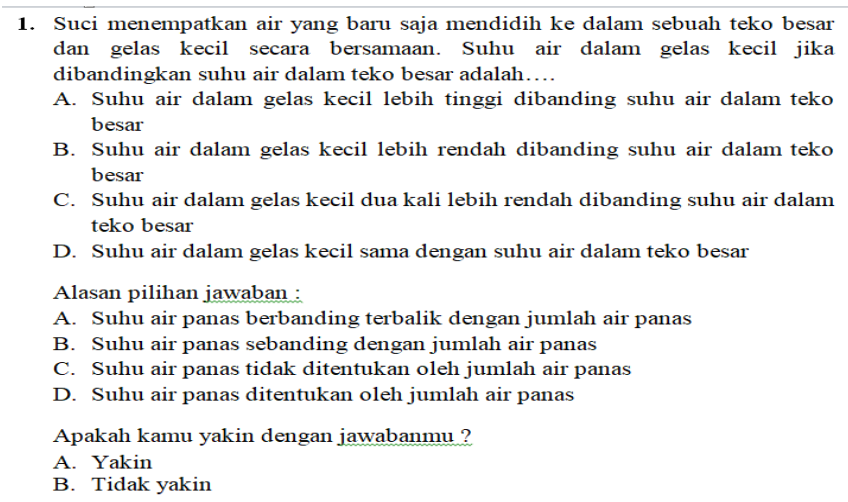

Gambar 9. Soal Nomor 1 
Indikator soal nomor 10 yaitu Menjelaskan konsep suhu. Pada soal ini teridentifikasi miskonsepsi yaitu suhu air panas ditentukan oleh jumlah air panas. Ini merupakan miskonsepsi yang paling banyak dialami peserta didik secara keseluruhan yaitu $79 \%$ dari total sampel. Peserta didik menganggap semakin banyak jumlah air panas maka suhu air semakin tinggi, padahal sebenarnya Suhu air dalam gelas kecil sama dengan suhu air dalam teko besar, Karena suhu suatu benda tidak bergantung banyak atau sedikitnya suatu benda.

Dari hasil analisis data diatas, maka dapat diketahui bahwa miskonsepsi terjadi di setiap butir soal. Secara keseluruhan tingkat miskonsepsi peserta didik pada materi suhu dan kalor termasuk dalam kategori tinggi. Hal ini sesuai dengan hasil penelitian (Silung, Kusairi, \& zulaikah, 2016) bahwa konsep-konsep terkait konsep suhu dan kalor merupakan konsep yang cukup sulit dipahami peserta didik sehingga sering terjadi miskonsepsi. Hal ini juga sejalan dengan hasil penelitian (Arslan, 2012) bahwa miskonsepsi terjadi karena peserta didik menjawab dengan salah pada soal yang diberikan tetapi memiliki tingkat kepercayaan yang tinggi terhadap jawaban mereka.

\section{KESIMPULAN}

Berdasarkan hasil penelitian yang dilakukan tentang identifikasi miskonsepsi mata pelajaran IPA peserta didik kelas VIII SMPN terakreditasi A di Kabupaten Gowa disimpulkan bahwa:

1. Tingkat miskonsepsi mata pelajaran IPA peserta didik laki-laki kelas VIII SMPN Terakreditasi A di Kabupaten Gowa termasuk dalam kategori tinggi.

2. Tingkat miskonsepsi mata pelajaran IPA peserta didik perempuan kelas VIII SMPN Terakreditasi A di Kabupaten Gowa termasuk dalam kategori tinggi.

3. Tingkat miskonsepsi mata pelajaran IPA peserta didik kelas VIII SMPN Terakreditasi A di Kabupaten Gowa secara keseluruhan termasuk dalam kategori tinggi.

\section{DAFTAR PUSTAKA}

Andarini, T. d. (2012). Pembelajaran Biologi Menggunakan Pendekatan (Contextual Teaching and Learning) Melalui Media Flipchart dan Video Ditinjau dari kemampuan verbal dan Gaya Belajar. Jurnal Inkuiri , 93-104.

Arikunto, P. S. (2016). Dasar-Dasar Evaluasi Pendidikan Edisi 2. Jakarta: Bumi Aksara.

Arslan, H. C. (2012). A Three-Tier Diagnostic Test to Assess Pre-Service Teachers' Misconceptions about Global Warming, Greenhouse Effect, Ozone Layer Depletion, and Acid Rain. International Journal of Science Education .

Carey, S. (1986). Cognitive Science and Science Education. American Psychologist .

Cetin-Dindar, A. \&. (2011). Development of a Three-Tier Test to Assess High School Students Understanding of A Cids and Bases. Procedia Social and Behavioral Science .

Hasan, S. B. (1999). Misconception and the certainty of response index (CRI). Physics Education.

Liliawati, W. \&. (2008). Identifikasi Miskonsepsi Materi IPBA di SMA dengan Menggunakan CRI (Certainly of Response Index) dalam Upaya Perbaikan Urutan Pemberian Materi IPBA Pada KTSP. Jurnal Pendidikan Tenologi dan Kejuruan, Vol VI.

Pesman, H. \&. (2010). Development of a Three-Tier Test to Assess Misconceptions About Simple Electric Circuits. The Journal of Educational Research .

Silung,Sri Nurul W., Kusairi \& Zulaikah.(2016). Diagnosis Miskonsepsi Siswa SMA di Kota Malang pada Konsep Suhu dan Kalor Menggunakan Three Tier Test. Jurnal Pendidikan Fisika dan Teknologi.

Supamo, P. (2013). Miskonsepsi dan Perubahan Konsep dalam Pendidikan Fisika. Jakarta: PT. Grasindo. 


\section{Dewi Kartika}

Mahasiswa Program Studi Pendidikan IPA FMIPA UNM, aktif melakukan penelitian pada bidang Pendidikan IPA, dapat dihubungi melalui pos-el: dewi.kartika166@yahoo.co.id.

\section{Ratnawaty Maming}

Dosen Program Studi Pendidikan IPA FMIPA UNM, aktif melakukan penelitian pada bidang Pendidikan IPA.

\section{Muh Tawil}

Dosen Program Studi Pendidikan IPA FMIPA UNM, aktif melakukan penelitian pada bidang Pendidikan IPA. 